\title{
The Dance of the Future: Wassily Kandinsky's Vision, 1908-1928
}

Michael Huxley

\section{ABSTRACT}

One can best glean painter Wassily Kandinsky's contribution to ideas about dance by looking at the totality of his writings. Kandinsky conceptualized dance as part of his theories for a new abstract art in his major book Concerning the Spiritual in Art. I consider his 1912 statement on the dance of the future as a modernist statement in its time. Kandinsky's idea for a new form of theater, Bühnenkomposition, incorporated dance, as his script for The Yellow Sound demonstrates. His later writings in Moscow and at the Bauhaus in Weimar and Dessau reveal his concern for what the modern dance might achieve. In 1928, Kandinsky finally realized his ambition to stage a new form of synthetic theater in a production of Mussorgsky's Pictures at an Exhibition.

\section{KEYWORDS}

Kandinsky, abstract art, modern dance, modernist, spirituality, synthetic theater

\section{Introduction}

In the early twentieth century, during a period of decisive developments in modernism, the painter Wassily Kandinsky made dance an integral part of his vision for the future of art. In the twenty years between 1908 and 1928, he contributed more than any other contemporary painter to a new idea for a modern dance. He worked closely with a significant modern dancer, Alexander Sacharoff, and wrote about another, Gret Palucca. He commented on ballet and the emergent new dance of the time. He wrote a number of new types of stage works"Bühnenkomposition" as he called them * - and collaborated with other artists, musicians, and

\footnotetext{
* Bühnenkomposition translates as "stage composition." Kandinsky used the term to describe his writings and experiments for the stage at a time when he was painting a series of pictures that he termed komposition.
} 
dancers, only to have plans for performance thwarted by the outbreak of The Great War in 1914. Fourteen years later, Kandinsky realized part of his dream of a monumental artwork with dance as a key component, Pictures at an Exhibition (1928), where his ideas about dance were first seen in practice.

Kandinsky's contributions to the literature on art treated dance as an equal partner with music and the visual arts. Indeed, Über das Geistige in der Kunst (1912), published in English as The Art of Spiritual Harmony (1914), and known today as Concerning the Spiritual in Art, ${ }^{*}$ included a major statement on the theory of dance, which preceded what many modern dancers themselves wrote and practiced. Taken together, his writings - which he derived from his practice — constitute a vision for dance both of and ahead of its time. He acknowledged this when he spoke of der Tanz der Zukunft. M. T. H. Sadler translated this

* The publication date of Über das Geistige in der Kunst reads 1912, but the book appeared in December 1911. M. T. H. Sadler's English translation, The Art of Spiritual Harmony, appeared simultaneously in London and Boston in 1914. Later editions adopted the more accurate translation, Concerning the Spiritual in Art. In this article, I refer to pagination in the Boston 1914 edition because the English-speaking world read this translation for three decades following its publication. Where necessary for the sake of clarity, I refer to the Rebay 1946 translation and the Lindsay and Vergo 1982 translation. Wassily Kandinsky, Über Das Geistige in Der Kunst: Insbesondere in Der Malerei (Munich: Piper, 1912); Wassily Kandinsky, The Art of Spiritual Harmony, trans. M. T. H. Sadler (Boston and New York: Houghton Mifflin, 1914); The Art of Spiritual Harmony, trans. M. T. H. Sadler (London: Constable, 1914); On the Spiritual in Art, trans. and ed. Hila Rebay (New York: Solomon R Guggenheim Foundation, 1946); Wassily Kandinsky, On the Spiritual in Art, trans. Kenneth C. Lindsay and Peter Vergo, in Kandinsky: Complete Writings on Art (1982; repr., New York: Da Capo, 1994), 114-220. 
phrase for the English edition as “dance-art of the future.” Hila Rebay's 1946 translation and Kenneth Lindsay and Peter Vergo's 1982 and 1994 translations restored the sense of the original German: "dance of the future."1

This article considers how Kandinsky, who was not a dancer but a painter, made a major contribution to thinking about what form a dance of the future might take. He challenged early twentieth-century notions of the place of dance by extending his artistic practice to collaborate with dancers, musicians, and other artists in a search for a new form of stage composition. He has been recognized as one of the key figures in the visual arts, notably in his contributions to the developments of abstraction and theories of art. His writings appeared in key publications in Munich, Moscow, Weimar, and Dessau in association with major modern art organizations of the period: The Neue KünstlerVereinigung, the Blaue Reiter group, the Institute of Artistic Culture, and the Bauhaus respectively. A number of scholarly articles on aspects of Kandinsky's work have mentioned dance. One or two have considered Kandinsky and dance specifically, but have looked at only part of his oeuvre. ${ }^{2}$ In this essay, I examine the totality of his ideas for dance in writings first published in 1912, 1920, 1923, 1926, and 1927, as well as the context in which his ideas arose. I have taken the "dance of the future" as a central focus because it is an idea to which Kandinsky kept returning. Thus, I begin with a consideration of his first reference to dance, and then give a detailed examination of the situation in which his thinking and practice arose in Munich. This entails an examination of the period 1908-1914, discussion of his theories of art articulated in this period, and contextual reference to his collaborators in dance and music. In doing so, I locate his ideas and practices in the broader dance context of the time with regard to what was referred to, and later became known as, modern dance. I follow this thread through his time in Moscow, especially around 1920-1921, and then his move to the 
Bauhaus. Lastly, I examine dance in the only realization of his ideas onstage in a 1928 performance.

\section{The dance of the future}

What did Kandinsky mean when he spoke of "the dance of the future"? He wrote Über das Geistige in der Kunst while in Munich; the original manuscript is dated August 3, 1909. ${ }^{3} \mathrm{He}$ criticizes the ballet of the time: European ballet on the cusp of the changes wrought by Ballets Russes following their inaugural performances in Paris in May 1909. For Kandinsky, the ballet was incapable of dealing with abstract ideas. On the one hand, Isadora Duncan had "forged a link between the Greek dancing and that of the future" and was therefore working in a way similar to many contemporary painters who looked to the past for a way of breaking with the present. But on the other, crucially, "in dance as in painting this is only a stage of transition. In dancing as in painting we are on the threshold of the art of the future." 4 That is to say, while Kandinsky acknowledged Duncan's contribution, he looked beyond what she was offering at the time. Instead, he sought a dance that would deal with abstraction — which was one of his central goals. Lindsay and Vergo's translation encapsulates the full force of his comparison:

The reformers of ballet have in our own times turned their eyes toward forms from the past, whence they seek help even today. Thus originated the link forged between Isadora Duncan and Greek dance and the dance of the future. This happened for exactly the same reasons as those that prompted the painters' search for help among the primitives. Of course in the case of dance [as in the case of painting], this is only a transitional stage. We are faced with the necessity of creating a new dance form, the dance of the future. ${ }^{5}$

Thus, Kandinsky established the need for the dance of the future to go beyond the transitional state represented by Duncan's modern take on Greek dance. 
In The Art of Spiritual Harmony, Kandinsky proposes dispensing with “story-telling” or "anecdote" and learning from the spiritual possibilities afforded by music. Eschewing such concrete, literal elements will result in composition on a higher plane, he implies:

The achievement of the dance-art of the future will make possible the first ebullition of the art of spiritual harmony - the true stage composition.

The composition for the new theatre will consist of these three elements:

(1) Musical movement

(2) Pictorial movement

(3) Physical movement

and these three, properly combined, make up the spiritual movement, which is the working of the inner harmony. They will be interwoven in harmony and discord as are the two chief elements of painting, form and colour. ${ }^{6}$

Lindsay and Vergo's later translation gives a much better sense of the way the elements work together:

This dance of the future, which is thus raised to the level of music and painting today, will in the same instant become capable of contributing as a third element to the creation of a form of stage composition that will constitute the first work of Monumental Art.

Stage composition will consist initially of these three elements:

1. Musical movement,

2. Pictorial movement,

3. Dance movement. ${ }^{7}$

Significantly, this section of the chapter is accompanied by a reproduction of one of Kandinsky's new paintings as compositions, Composition II. The juxtaposition of textual words and abstract image suggests that here Kandinsky proposes a new form of stage 
composition to achieve an artwork that, like this series of his paintings, realizes the spiritual in abstraction. ${ }^{*}$ And dance is integral to this direction.

However, the "dance of the future" is most commonly associated not with Kandinsky, but with Duncan by virtue of her lecture to the Berlin Press Association, published as The Dance of the Future: A Lecture in $1903 .^{\dagger}$ While both Duncan and Kandinsky used the phrase der Tanz der Zukunft, it is difficult to ascertain whether or not Kandinsky was deliberately citing Duncan. In contradistinction, I argue that the phrase meant something different to Duncan and Kandinsky. An understanding of how it was used by Duncan helps set up a discussion of Kandinsky's unique ideas for dance.

Duncan made her statement at the start of her extensive performing career in Europe. The original statement, as published in 1903 in German and English, with an introduction by translator Karl Federn, begins "I am asked to speak upon the 'dance of the future'-yet how is it possible?"8 In other words, Duncan was responding to an invitation of that nature, and

\footnotetext{
* Magdalena Dabrowski, in her definitive account of all the compositions that Kandinsky painted between 1909 and 1939, refers to their purpose as "the creation of a new spiritual realm." Magdalena Dabrowski, Kandinsky Compositions (New York: The Museum of Modern Art, 1995), 11.

${ }^{\dagger}$ Isadora Duncan, Der Tanz Der Zukunft (The Dance of the Future): Eine Vorlesung [A Lecture], ed. Karl Federn (Leipzig: Eugen Diederichs, 1903); republished as The Dance (New York: Forest Press, 1909). Federn published the lecture, along with an introduction, in book form, but it would not be accurate to say that Duncan wrote The Dance of the Future as a book.

* In her definitive documentation of Kandinsky’s period in Munich, Peg Weiss makes such a claim. Peg Weiss, Kandinsky in Munich: The Formative Jugendstil Years (Princeton, NJ: Princeton University Press, 1979), 203, fn. 90.
} 
not, as many would have it, proclaiming a manifesto. This crucial first paragraph is omitted from the abbreviated version of the talk published in Theatre Arts Magazine of 1917; from the 1928 collection of her writings, The Art of the Dance; and from much of the subsequent literature. $^{9}$

In her much-quoted lecture, Duncan discusses her debt to the Greeks of antiquity and then goes on to identify how the dance of the future will come about, saying, "The new school of the dance should be that movement that is in harmony with and will develop the highest form of the human body. I intend to work for this dance of the future." ${ }^{10}$ In the impassioned conclusion to her lecture, Duncan talks of the "dancer of the future." Throughout the lecture, Duncan refers to dancers as women, especially in the concluding paragraphs of the lecture. Thus, for Duncan, the dancer of the future-referred to as "she"is a woman empowered by dancing: "the highest intelligence in the freest body!"11

\section{Munich}

In 1896, Kandinsky moved to Munich, where he resided when not touring Europe. He moved into an apartment in the Schwabing district in 1908 and then to Murnau, a small market town just south of the city, where he was based from 1909 until 1914. Duncan first performed in Munich in 1902. The theater scholar Naoko Kobayashi-Bredenstein suggests that Kandinsky attended Duncan's dance concerts in Munich in 1902 and mentioned her several times in his subsequent letters to the artist Gabriele Münter, with whom he had a relationship. ${ }^{12}$ It is therefore not surprising to find that he mentions Duncan in The Art of Spiritual Harmony when he talks of the dance of the future. However, what he would have seen in 1902 would certainly have been Duncan's early Greek dances - and at a time before her address on the dance of the future to the Berlin Press Club.

Duncan subsequently performed in Munich in 1904, 1906, and 1907, and pupils from her school performed recitals in 1907 and 1910. The city was a major center for what art 
critic Ernst Schur termed Der Moderne Tanz (The Modern Dance) for his eponymous book, published there in $1910 .{ }^{13}$ In talking of the new modern dance, he refers to Duncan, Rita Sacchetto, the Wiesenthal Sisters, and Ruth St. Denis. Indeed, all these and a number of other young women of the new dance performed in Munich, including Maud Allan in 1907, and Sent M'Ahesa and Clotilde von Derp in 1910. In 1911, the year of publication of Kandinsky’s first book, Munich audiences saw von Derp dancing in Max Reinhardt productions, and the city was at the center of the scandal that surrounded the arrest of Adorée Villany for dancing naked. ${ }^{14}$ Duncan's public performances in Munich occurred at major venues in the center of the city, and received commentary in the press. For instance, as Claudia Jeschke and Gabi Vettermann show, critics described Duncan's 1906 performances in Berlin and Munich in detail, giving us a sense of her performance at this time. ${ }^{15}$ Duncan's programs in this period, during the early part of her European career, included "Greek Dances," accompanied by solo piano, with music by Brahms, Chopin, Schubert, and others. Interestingly, she did not use the term Moderne Tanz or modern dance in her writings or programs at this time. Writers such as Schur (1910) and later Hans Brandenburg (1913) in Germany, and Flitch (1912) in England, attributed the term. ${ }^{16}$

Readers of the 1914 English translation of Kandinsky's book by Sadler, published in London as Concerning the Spiritual in Art and in Boston as The Art of Spiritual Harmony, might have been confused by the translator's footnote, which tries to clarify exactly what sort of dance Kandinsky refers to. Sadler suggests that Vaslav Nijinsky’s Le Sacre du Printemps (1913) or L'Après-midi d'un Faune (1912), or the Eurhythmics of Émile Jaques-Dalcroze, offer better examples than Duncan of what Kandinsky was striving for. ${ }^{17}$ However, Kandinsky would have seen neither of Nijinsky's dances before submitting the manuscript of his 1912 book; and his knowledge of Jaques-Dalcroze also came later, not least through Sadler. Here, Sadler had the benefit of hindsight, having seen Jaques-Dalcroze's Eurhythmics 
in action in 1912, shortly after visiting Kandinsky. ${ }^{*}$ And the modernist journal that Sadler edited, Rhythm, had thoroughly covered Diaghilev's Russian Ballet, which performed in London for the first time in June 1911.

Nonetheless, Kandinsky had had direct experience of working with a dancer before writing his book. In 1908 he had begun experiments with Alexander Sacharoff, two years before the dancer's debut at the Munich Odeon. Research first by Ian Strasfogel, and later by Shulamith Behr and Rainer Stamm, has shown the considerable extent to which Kandinsky and Sacharoff, along with the composer Thomas de Hartmann, collaborated. ${ }^{18}$ At the very time when Kandinsky was editing his manuscript of Über das Geistige in der Kunst, he was exploring the ideas of synesthesia and synthetic art with Sacharoff.

Kandinsky recalled the way in which he experimented with music and dance in a statement made in Soviet Russia in 1920. Although he mentioned neither de Hartmann nor Sacharoff by name, it is fairly clear that these are the people to whom he refers. ${ }^{\dagger} \mathrm{He}$ described how de Hartmann would choose one of Kandinsky's watercolors and then improvise music on the piano. Then Sacharoff, having no knowledge of which watercolor de Hartmann had selected, would dance. The dancer would then identify the painting in question. Kandinsky recalled,

\footnotetext{
*See Adrian Glew, “'Blue Spiritual Sounds': Kandinsky and the Sadlers 1911-1916,” The Burlington Magazine, vol. 139, no. 1134 (1997): 600-615. Ramsay Burt and I also discuss this in "Concerning the Spiritual in Early Modern Dance: Émile Jaques-Dalcroze and Wassily Kandinsky Advancing Side by Side," Journal of Dance, Movement and Spiritualities, vol. 1, no. 2 (2014): 251-69.

${ }^{\dagger}$ Kenneth C. Lindsay and Peter Vergo, as translators and compilers, suggest that the anonymous dancer was "almost certainly Aleksandr Sakharov [Alexander Sacharoff]." Lindsay and Vergo, Kandinsky: Complete Writings on Art, 473.
} 
I myself had the opportunity to carry out some small experiments abroad with a young musician and a dancer. From several of my water-colours the musician would choose one that appeared to him to have the clearest musical form. In the absence of the dancer, he would play this water-colour. Then the dancer would appear, and having been played this musical composition, he would dance it and then find the watercolour he had danced. ${ }^{19}$

Kandinsky does not state precisely which of his works he lent to these experiments. However, between January 1907 and January 1910, he produced no fewer than thirty-five watercolors. Barnett, in her definitive Catalogue Raisonée, identifies one work from 1908-1909 as the cover or title page for an Album with Music and Graphics, the book Kandinsky was working on with de Hartmann, but which was not finally published. ${ }^{20}$ It seems reasonable to surmise that this watercolor and others associated with it were used in the experiments. At least two other watercolors from this period could be identified as potential objects of experiment: Musicians in a Landscape and Two Figures in Front of a Hill with a Tree (both 1908-1909). All of these watercolors are figurative. However, they are consistent with the technical experiments that Kandinsky was conducting at the time, which led to his development of abstraction just a couple of years later. So Kandinsky's first experiments with dance occurred at the precise moment he was beginning to work toward abstraction in his own practice.

Stamm's essay on Sacharoff goes into some detail about the dancer's collaborations with de Hartmann and Kandinsky. Stamm suggests that, although their direct working relationship was confined to 1908 , within that short time, they made considerable advances. Most notably, Kandinsky and de Hartmann's original performance idea for a work to be made with Sacharoff, based on Hans Christian Andersen's fairy tales, developed into an exploration of Daphnis and Chloe, complete with a model stage set designed by Kandinsky. ${ }^{21}$ Daphnis and Chloe was never produced, but one of the ideas for this dance appears again in 
Kandinsky's first sketch for his stage composition Giants, the forerunner of The Yellow Sound. ${ }^{22}$ Kandinsky worked with de Hartmann and Sacharoff at a time when he was developing his ideas of composition and abstraction and also writing works for the theater. His idea of a dance of the future developed out of these experiments as much as his observations of the deficiencies in ballet. At the same time, Kandinsky was formulating his ideas on spirituality in art as a modernist response to what he saw as the moribund stasis of all the arts. He considered dance to be part of a greater project. His writings of the period 1910-1914 - theoretical, reflective, and compositional in nature - established a basis for the development of his artwork and writing for the next two decades. Indeed, as we shall see, Kandinsky continues to mention dance in texts written in Soviet Russia and at the Bauhaus.

The "spiritual" was a central concern for Kandinsky in his art practice, his theoretical writings, and his interest in dance. Therefore, it is important to outline what he meant by the term, which differs from recent ideas of spirituality, not least in relation to dance. ${ }^{*}$ First, one must consider the question of translation, and second, Kandinsky's highly developed intellectual sense of both the history of modern art and of the panorama of contemporary thinkers and practitioners. Peg Weiss, the major authority on Kandinsky's Munich period, gives a detailed account of the difficulties of translation of his writings in general and "of 'das Geistige' in particular." ${ }^{, 3}$ She points out that in German the terms Geist and geistig "suggest almost equally the notion of incorporeal or immaterial and the notions of mind, intellect or genius"; whereas, in English "the word 'spiritual' . . is almost exclusively concerned with the incorporeal, the notion of the soul, and the idea of the supernatural., ${ }^{24}$ Moreover, in English "spiritual" is usually defined in religious terms. Weiss comments on the confusion that this might cause when considering Kandinsky’s 1912 book Über das Geistige

\footnotetext{
* See, for instance, the range of contemporary interpretations of spirituality in the Journal of Dance, Movement and Spiritualities, first published in 2014.
} 
in der Kunst in reference to its usual translations into English, where the term "spiritual" is used in all cases. ${ }^{25}$ This is not to say that Kandinsky was unaware of or uninfluenced by spiritual matters in the English sense. In his Reminiscences of 1913, Kandinsky searches for an understanding of what might be meant by spirituality in terms of the "inner life of a work of art," making direct reference to Christ." Furthermore, in Über das Geistige in der Kunst Kandinsky alludes to certain figures and movements concerned with "the spiritual" in a supernatural sense, notably Madame Blavatsky, Rudolf Steiner, and Theosophy. However, Lindsay and Vergo are at pains to point out that Kandinsky referred to these thinkers among many other writers, including Karl Marx and Edgar Allan Poe. Moreover, they contend that at this time Kandinsky deliberately distanced himself from the occult and from Theosophy. ${ }^{26}$

Kandinsky drew on his considerable knowledge of the history of art in seeking ways to deal artistically with what he saw as the increasingly materialistic culture of a world that, at that historical juncture, was about to be precipitated into the mechanized slaughter of the Great War. So Kandinsky was well versed in a broad range of ideas of the spiritual in the artistic sense, in the culturally specific German sense (das Geistige), and in the English sense (religious/transcendental). What seemed to matter most to him was the sense in which the experience of art can deal with the ineffable or inexpressible (as Weiss would have it) - the artwork's inner life_-even while communicating through physical elements: line and color in painting, human movement in dance. This, for Kandinsky, was what an artist, and art, could do. It is this sense that I have in mind in future references to "the spiritual." And it was this sense of the spiritual, among other forces, that impelled Kandinsky toward abstraction. ${ }^{\dagger}$

\footnotetext{
*Lindsay and Vergo's translation and notes, with Kandinsky’s own footnotes, are very helpful here: Wassily Kandinsky, "Reminiscences," in Lindsay and Vergo, Kandinsky: Complete Writings on Art, 355-82.

${ }^{\dagger}$ Ramsay Burt and I have explored some aspects of Kandinsky’s ideas of the spiritual in an
} 
In his paintings of this period, Kandinsky realized key ideas about abstraction, content, and form and how a work of art can resonate spiritually with the artist and the viewer. For him, the line, the figurative, and the narrative recede in importance; it is the "inner sound" of the painting that evokes a response in the viewer. His seven Compositions painted between 1910 and 1913 are all concerned with this central spiritual idea (see Figure 1). In the conclusion to Concerning the Spiritual in Art, Kandinsky characterizes three types of painting: the impression, the improvisation, and the composition. ${ }^{27}$ The first concerns the artistic realization of an external impression; the second, a "largely unconscious, spontaneous expression of inner character." Kandinsky painted many of these improvisations during the period. Kandinsky describes the third type as "an expression of a slowly formed inner feeling, which comes to utterance only after a long maturing. This I call a 'Composition.' In this, reason, consciousness, purpose play an overwhelming part. But of the calculation nothing appears, only the feeling." 28

\section{$<$ Please place Figure 1 near here. $>$}

In an essay published to accompany an exhibition that included his earlier paintings such as Composition II, created in Odessa in 1910-1911, Kandinsky made a first explicit article that compares his writings to those of Émile Jaques-Dalcroze. Our starting point here is the meetings of both artists separately with M. T. H. Sadleir (Sadler) and his father Michael Sadler in 1912. Michael Huxley and Ramsay Burt, "Concerning the Spiritual in Early Modern Dance: Émile Jaques-Dalcroze and Wassily Kandinsky Advancing Side by Side,” Journal of Dance, Movement and Spiritualities, vol. 1, no. 2 (2014): 251-69.

* Magdalena Dabrowski gives an excellent account of these paintings, placing them in the context of Kandinsky's Munich period, and relating them to his work with Arnold Schoenberg, but failing to mention his involvement with dance and, particularly, Sacharoff. Dabrowski, Kandinsky Compositions. 
statement about his idea for a new spiritual art. He begins by saying that the "work of art comprises two elements: the inner and the outer." ${ }^{29}$ He goes on to describe how the inner element, the emotion in the soul, elicits a corresponding vibration in the onlooker; moreover, the artist should seek a form to bring this about. In this essay, Kandinsky uses the term "monumental art" for the first time, talking of the spiritual in the "battles against materialism"30 and laying out what he calls the "essentially immutable means [of artistic expression]. ${ }^{\prime 31}$ He does not mention dance, or theater, at this stage, but his interest in these forms as part of the quest for the spiritual becomes apparent in his later writings on the question of stage composition, Bühnenkomposition - a term that he coined.

Kandinsky developed his idea of Bühnenkomposition while he was working with de Hartmann and Sacharoff. His collaborations with the composer and the dancer included work on, and specifically designs for, a version of Daphnis and Chloe for Sacharoff. A number of researchers have reported that Kandinsky began work on his other stage compositions in the same year: Behr, Thomas Hines, Kobayashi-Bredenstein, Stamm, and Susan Stein have traced the writings from the original documents. ${ }^{32}$ They give slightly different pictures, but it is fair to say that Kandinsky, in the period 1908-1914, worked on no fewer than five possible stage compositions. Only one was published. None were realized onstage. Moreover, although the original idea for Giants came as early as 1908, the work did not fully mature into an example of his stage compositions until it was published in 1912 (in preference to Green Sound or Black and White) as The Yellow Sound. His stage experiments developed at a time when he was collaborating with artists from a range of disciplines.

\section{$<$ Put Chart 1 near here. $>$}

In 1909, Kandinsky and others artists, including Alexej von Jawlensky, Münter, and Sacharoff, founded the New Artists Association Munich (Neue Künstler-Vereinigung München $[\mathrm{NKVM}])$. One of the central tenets of the organization was a search for an inner 
synthesis in art. ${ }^{*}$ Two years later Kandinsky withdrew and, with the artist Franz Marc, drew on a group of artists of various disciplines to stage an exhibition and publish an almanac, the Der Blaue Reiter (The Blue Rider). In 1912, when Kandinsky made his plea for the dance of the future in Über Das Geistige in der Kunst, it was closely followed by the first edition of The Blaue Reiter Almanac. The Almanac showcased Kandinsky's essay on stage composition as a preface to the script of The Yellow Sound, in what could be said to be the climactic finale to the volume. It also featured essays on music by de Hartmann, and pictures and music by Kandinsky's new friend Arnold Schoenberg.

Kandinsky clearly intended for his Bühnenkompositions to be staged, and he was actively involved in the flourishing Munich theater scene. Munich had been one of Germany's centers for experiments in theater including, but not limited to, the work initiated by Georg Fuchs and Max Reinhardt. Weiss makes a strong case for the argument that Fuchs had a significant influence on Kandinsky's thinking about theater in the period before $1910 .^{33}$ It was Fuchs who established the Münchener Künstlertheater (Munich Artists’ Theatre), which opened in May 1908. He also wrote extensively about what he termed the "theatre of the future," notably in Die Schaubühne der Zukunft (1905), where he refers to Duncan; in Der Tanz (The Dance, 1906), which focused on dance in particular, and in his 1909 book on the Munich Artists' Theatre. ${ }^{34}$ It was at Fuchs's new theater that Kandinsky envisaged his new stage work. Another significant figure in the Munich theater scene was Hugo Ball, whom Kandinsky met in 1912. In 1913, Ball became resident playwright and critic at the Munich Kammerspiele. Ball incorporated Kandinsky’s Yellow Sound in a proposed program

\footnotetext{
* In his January 1910 letter from Munich for the journal Apollon, Kandinsky describes the aspirations of the NKVM, quoting from their publicity statement. He emphasizes the need for artistic synthesis. Kandinsky (1910) in Lindsay and Vergo, Kandinsky: Complete Writings on Art, 62.
} 
of new theater to be staged at the larger Künstlertheater in 1914. Early that same year, Kandinsky worked on another stage composition Violett (Violet), drafting his own sketch for the music. In June 1914, Ball organized a series of matinees to be performed at the Munich Kammerspiele. The program was to include the newly completed Violett. Thus, in 1914, plans existed for the realization of Kandinsky's stage works. But his aspirations for a new form of theater, with dance as a key component, were cut short by the outbreak of the Great War in August.

Kandinsky's Bühnenkompositions, and his idea of a monumental artwork of which dance would be an integral part, were startlingly new. He theorized a new form of theater as a way of dismantling the borders that he saw between traditional theatrical forms. He wrote that the existing stage works of drama, opera, and ballet were "separated from one another by high walls." Artists, he said, focused on external forms and this meant "they gradually become more orthodox, and every minute change appears revolutionary., ${ }^{, 35}$

Kandinsky further explored his ideas on composition, spirituality, and abstraction in his treatment of color and form in the writings published in Der Blaue Reiter Almanac in 1912. His essay, or preface, "Über Bühnenkomposition" ("Stage Composition") and the accompanying composition, Der gelbe Klang: Eine Bühnenkomposition (The Yellow Sound: A Stage Composition), examines how art elements could be synthesized to give a spectator an inner experience of a spiritual nature. He offers an alternative to the externally focused art disciplines, separated by walls, by relating three "inner," or medium-specific, elementssound, body, and color tones — to movement. In short, Kandinsky sees the stage composition of the future as the unification of these mediums through movement: " 1 ) musical sound and its movement; 2) bodily spiritual sound and its movement, expressed by people and objects; 3) colour-tones and their movement (a special resource of the stage). ${ }^{36}$ A reproduction of 
Composition $V(1911)$ follows the essay and precedes the first full Bühnenkomposition to be published: The Yellow Sound.

The Yellow Sound presents a Prelude and Six Pictures (or scenes), which explore relationships between sound, movement, and color. In his stage compositions, Kandinsky incorporates dancers in a completely new way. They could be thought of as performing "abstract dance," although this is not a term that Kandinsky himself used explicitly. He treats the dancers non-figuratively, as if they were moving colors. Five yellow giants glide onto the stage in Picture Two. They are not so much traditional narrative giants as imposing yellow presences. "People" in flowing robes and people in tights become part of the action. The following passages from Picture Five, the complex climax, give a sense of the work, the dancers, and their colors:

The giants remain motionless. From the left appear many people, clad in tights of different colors. Their hair is covered with the corresponding color. Likewise their faces. (The people resemble marionettes.) First there appear gray, then black, then white, and finally different-colored people. The movements of each group are different; one proceeds quickly forward, another slowly, as if with difficulty; a third makes occasional merry leaps; a fourth keeps turning around; a fifth comes on with solemn, theatrical steps, arms crossed; a sixth walks on tiptoe, palm upraised, etc. ${ }^{37}$ Kandinsky describes the stage movements and intentions of a central figure, a man in white. In this description, it is possible to discern some of his thinking about dance and music. The script suggests that Kandinsky had an actual dancer in mind as he envisaged this scene. Such a dancer is likely to have been Sacharoff, although Kandinsky makes no direct mention of him. Ian Strasfogel, who in 1982 directed the first full realization of The Yellow Sound with a reconstruction of de Hartmann's music, goes so far as to suggest that Sacharoff worked on the movements for the man in white c. $1913 .^{38}$ The script continues: 
At precisely these moments, one of the white figures on the left (fairly far back) makes indefinite, but very much quicker movements sometimes with his arms, sometimes with his legs. From time to time he continues one movement for a longer space of time, and remains for several moments in the corresponding position. It is like a kind of dance, only with frequent changes of tempo, sometimes corresponding with the music, sometimes not. (This simple action must be rehearsed with extreme care, so that what follows produces an expressive and startling effect.) The other people gradually start to stare at the white figure. Many crane their necks. In the end, they are all looking at him. This dance ends, however, quite suddenly; the white figure sits down, stretches out one arm as if in ceremonious preparation and, slowly bending this arm at the elbow, brings it towards his head. The general tension is especially expressive. The white figure, however, rests his elbow on his knee and puts his head in his hand. For a moment, it becomes dark. ${ }^{39}$

In The Yellow Sound, and especially in these passages, Kandinsky gives an idea of what "the dance of the future" might be like.

What he envisages is dancers who express, through their movements and the threedimensional development of their relations to one another, correspondences to what a viewer might see in the two-dimensional surface of an abstract painting. Kandinsky asks the audience to look at the dancers in quite a different way — as colored figures moving in synchrony or asynchrony. In doing so, Kandinsky invites viewers to enter into a different world, much as one might do when listening to music.

Indeed, Kandinsky was attempting to create a theatrical world that simply did not exist at that time. He was grappling with the whole question of the non-representational and how it might affect an audience. Thus, most obviously, he talks of the dancers as colored figures and, although their movements are clearly embodied, they do not stand in for anything 
other than the colors themselves. The way the figures move in relation to the music clearly differs from the dance of any previous period, especially in the idea of moving in and out of time with the music to produce a startling effect.

The actual dance of the future that Kandinsky's vision speaks to is, perhaps, one seen some half a century later in the work of Merce Cunningham. While nothing points to a direct comparison of their methods — Kandinsky and Cunningham worked from very different perspectives - the experience of their work and anticipated audience reception is of a similar nature. ${ }^{*}$ That is to say that both artists wished for their audience to view their work for the qualities within it, without direct reference to anything figurative or narrative. It is in this sense that dance helped Kandinsky to further his developing ideas of abstraction. He had already grappled with removing the figurative from the two-dimensional fields of his paintings. I believe that, because dance is embodied in the very real figures of the dancers, it offered the artist an implicit challenge. Equally, he was interested in the kinesthetic effect on

\footnotetext{
*In a 1952 essay, "Space, Time and Dance," Cunningham begins by saying “The dance is an art in space and time." And he concludes, "For me, it seems enough that dancing is a spiritual exercise in physical form, and that what is seen, is what is." Merce Cunningham, "Space,
} Time and Dance," transformation, vol. 1, no. 3 (1952), reprinted in Merce Cunningham: Fifty Years, ed. Melissa Harris (New York: Aperture, 1997), 66-67. In a 1955 essay, “The Impermanent Art," Cunningham speaks of dance, art, and music as follows: "If the dancer dances, everything is there. The meaning is there, if that is what you want. . . When I dance, it means: this is what I am doing. A thing is just that thing. In painting now we are beginning to see the painting, and not the painter nor the painted. We are beginning to see how a painted space is. In music, we are beginning to hear free of our well-tempered ears." Merce Cunningham, “The Impermanent Art," Arts, vol. 7, no. 3 (1955), reprinted in Harris, Merce Cunningham: Fifty Years, 86-87. 
the audience in the same way that he strove for a response to color from viewers of his paintings.

Although Kandinsky's description, given here, is brief, it gives a foretaste of what was to come. Such textual description was also unique in its time. None of the other artists whom we now know as modern dancers committed their choreography or compositions to print before 1920. While they might have written about their life in dance, they did not detail their work. It is evident that some, notably Laban, left notes or diary entries that give some impression of their thinking at this time. Interestingly, Oskar Schlemmer's diaries show how he, too, was thinking of a new type of dance, with a brief scenario written in Stuttgart in 1912, some five years before he began working with dancers and a decade before he realized dance in performance. ${ }^{40}$ However, I would contend that Kandinsky's script is the first detailed, published account of a modern dance composition prior to Mary Wigman's script for Die sieben Tänze des Lebens (The Seven Dances of Life) in 1921, almost a decade later. ${ }^{41}$ This has significance because, while The Yellow Sound was not realized on stage, it did enter the modernist discourse of the time as a contribution in The Blaue Reiter Almanac. However, we have no sense of its performance from the period.

\footnotetext{
* Reconstructions and re-imaginings from the 1970s onward are of a different nature. While many have attempted to stage The Yellow Sound, the earliest performances, including those in New York (1972), Paris (1976), Saint Baume (1975), and University of Leeds (1977), omitted the de Hartmann score. The first complete production, which reconstructed the music score, was Strasfogel's version for the Guggenheim Museum at the Marymount Manhattan Theatre on February 9, 1982. More recently, The Yellow Sound has been realized at Tate Modern in London (2011), at the Nationaltheater in Munich by the Bayerischen Staatsballett (2014), and at St Hilda's College, University of Oxford (2015).
} 
There are, of course, no reviews from critics. However, Kandinsky’s contemporaries did comment on his written ideas for a stage composition. At the time he was struggling to complete his own stage work Die Glückliche Hand (The Lucky Hand), Arnold Schoenberg wrote to his new friend on August 19, 1912, about The Yellow Sound, "Your stage composition pleases me extremely. Also the preface to it. I am completely in agreement .... It is exactly the same as what I have striven for in my Glückliche Hand, only you go still further than I in the renunciation of any conscious thought, any conventional plot."

In a lecture on Kandinsky's work at Cabaret Voltaire in Zurich in April 1917, Hugo Ball observed that Kandinsky "envisages a counterpositioning of the individual arts, a symphonic composition in which every art, reduced to its essentials, provides as an elementary form no more than the score for a construction or composition on the stage., Kandinsky's peers in music and theater were in artistic agreement with his aims. The Blaue Reiter Almanac had an original print run of just twelve hundred copies, and it went into a second edition in 1914. Although it did not have many subscribers, there is little doubt of its significance, because of the nature of its readership within artistic circles. At the same time, Kandinsky's paintings and writings were gaining significant attention in print, not least in the new modernist journals published in Britain and the United States. Edward Wadsworth, the Vorticist artist, gave a glowing review of the German original of Über das Geistige in der Kunst in the first edition of Wyndham Lewis's Blast in $1914 .{ }^{*}$

At this point, it is worth returning to the situation of the newly emerging modern dance of the period. In 1912, the year that Kandinsky's main ideas appeared in print, most of the emerging artists, including those mentioned earlier, were women who performed primarily as soloists. A number of these dancers continued to perform in Munich until the outbreak of the

\footnotetext{
* Wadsworth made his own translation, but the journal also noted the recent Sadler publication. Edward Wadsworth, "Inner Necessity," Blast, vol. 1 no. 1 (1914): 119-25.
} 
Great War in 1914. In addition, significant newcomers visited the city, most prominently Diaghilev's Ballets Russes in the autumn of 1912. Dancers based in Munich included Sacharoff and von Derp, who gave solo recitals and, in 1913, began to perform as a duet in a format that worked both in this period and later. Dance and Körperkultur (body culture) studios opened, including that of the Atelier für Tanz und Bühnenkunst (Studio for Dance and Performing Arts) Rudolf von Laban-Varalja at Klarstrasse 11. Laban, who had been living in the Schwabing district since 1910, was joined by aspiring performers Suzanne Perrottet and Marie Wiegmann (Wigman) in 1913. Wigman gave her first solo recital, performing Lento and Hexentanz on February 11, 1914, followed by her first full evening of works with Karl Weysel that April. It was in this cultural climate ${ }^{*}$ that Ball planned the performances of Kandinsky's Yellow Sound and Violet Curtain for 1914. As we know, they did not happen because of the war.

I have already noted that the term Moderne Tanz began to be used in this period to identify and discuss the work of many dancers. In Munich, Schur in 1910 and Brandenburg in 1913 published separate books titled Der Moderne Tanz, in which they began to chronicle the changes that were happening. ${ }^{44}$ Both consider solo women dancers, Duncan in particular; the

*From a dance point of view, Evelyn Doerr, John Hodgson, Carol-Lynne Moore, and Valerie Preston-Dunlop have variously discussed the Munich milieu and speculated on the relationship of Laban's ideas to those of Kandinsky's. See Evelyn Doerr, Rudolf Laban: The Dancer and the Crystal (Lanham, MD: Scarecrow Press, 2008); John Hodgson, Mastering Movement: The Life and Work of Rudolf Laban (London: Methuen, 2001); Carol-Lynne Moore, The Harmonic Structure of Movement, Music and Dance According to Rudolf Laban: An Examination of his Unpublished Writings and Drawings (Lampeter, UK: Edwin Mellen Press, 2009); Valerie Preston-Dunlop, Rudolf Laban: An Extraordinary Life (London: Dance Books, 1998). 
new dance schools; and the Ballets Russes. In Munich's cultural scene, Brandenburg was a prominent figure, writing on both dance and theater and associating with dancers in particular. His book includes a section on Sacharoff and some of Sacharoff's drawings of dance from 1910. He does not refer to Kandinsky at all in the first edition of his book or in subsequent editions from 1917 and 1921. This is hardly surprising because Kandinsky's stage compositions had not yet been realized. Brandenburg and Schur wrote about and for dancers, but Kandinsky's writings were not addressed directly to dancers. The use of the term "modern dance" by the dancers themselves was something that occurred much later; in the immediate prewar period, they preferred terms like "Greek dance" or Freie Tanz (free dance). The theater practitioner Ball used "modern dance" in describing his plans for a new “'International Society for Modern Art,' including not only the theater, but also modern painting, modern music, modern dance." ${ }^{25}$ In the same source, Ball also talks of his plans for a new book, The New Theater, to be published in October 1914 by Piper, Kandinsky's publisher. The book was to have included essays, sketches, and scenarios including contributions by Kandinsky, Marc, de Hartmann, and the choreographer Michel Fokine. In his memoirs of 1946, Ball recalled this period and how he had begun working with de Hartmann and Kandinsky. They came up with the idea that modern artistic theater should include the perspectives of Kandinsky on the total work of art, Fokine on ballet, and de Hartmann on music. ${ }^{46}$ Ball's vision for a theater of the future, like Kandinsky's, broke through the traditional barriers between recognized forms. However, the book was never published.

\section{Moscow}

Many scholars who have written recently about Kandinsky and dance focus on his time in Munich and his period at the Bauhaus, with greater emphasis on one or the other. ${ }^{47}$ In their narratives, Kandinsky's next major contribution was his brief essay on photographs of 
Palucca dancing. Most of the secondary literature on Kandinsky and dance misses statements made during his time in Moscow (1915-1921). His next major writing, which included dance at its center, shows quite clearly how he had developed his ideas about the state of dance as he found it, what it could contribute, and how it could do so. Crucially, the 1920 "Program for the Institute of Artistic Culture" reveals his further thinking about abstraction and dance and the continuing importance of the spiritual for him. ${ }^{48}$

In May 1920, The Institute of Artistic Culture in Moscow was established with Kandinsky at the helm for a short time. This research organization brought together a significant number of Russian avant-garde artists. Kandinsky presented a research program for the Institute in a paper given in June of that year. The proposed program was rejected by the Institute, and thus went unrealized in practice. Lindsay and Vergo, as well as Clark V. Poling, give accounts of the working of the Institute and Kandinsky's relationship with other artists. They point out that Kandinsky had become more and more estranged from the Russian avant-garde, including Kazimir Malevich and Aleksandr Rodchenko, for artistic reasons, not least of which included his continued insistence on the importance of intuition in the process of making work. ${ }^{49}$ Duncan arrived in Moscow on July 24, 1921, just six months before Kandinsky's departure. As part of a gala program to mark the fourth anniversary of the Russian Revolution, she performed her first solo program at the Bolshoi Theater on November 7 to a full house of 3,000 party members, trade union officials, members of the Red Army, and other apparatchiks. ${ }^{50}$ Kandinsky, who had by then distanced himself from both the party and the avant-garde, left Moscow for Berlin the following month.

The 1920 "Program for the Institute of Artistic Culture" sets out a research agenda for the future to consist of three main parts: (1) a theory of the individual arts; (2) a theory of the interrelationships of the individual arts; and (3) a theory of the monumental art or art as a whole. ${ }^{51}$ Dance appears as one of the individual arts, and, in the form of "movement of the 
body and its parts," as a key part of the monumental artwork. ${ }^{52}$ This is wholly consistent with what Kandinsky had written in 1912. Equally, he is still concerned with the dance of the future because "the dance is awaiting its reform with impatience, but whenever it comes near to this reform, it finds the entrance barred." ${ }^{, 53}$ Kandinsky proposes that the solution for advancement is to conduct research into the relationships between the elements of painting and those of dance: "It is essential to establish a link between the movement of lines and the movement of the human body (of the whole and of the individual parts) — to translate line into the movement of the body and the movement of the body into line." 54 Moreover, he restates an earlier distinction in the way the human body moves, differentiating between "the material aspect" and "the spiritual aspect — particularly the expression of emotional experiences" - and affirming his main interest in the second of these. ${ }^{55}$ In other words, in 1920, he further develops his earlier ideas, identifying a specific way forward for dance with an emphasis on the exploration of line. As we will see, this puts a different perspective on his later writings, especially his 1926 essay on the photographs of Palucca. In short, when Kandinsky explores line in movement and dance he still retains the idea of the spiritual. He also articulates a subtle distinction between movement that expresses emotion and, as he puts it, movement that is the expression of emotional experience. Moreover, he goes into considerable detail in analyzing different types of movement and refers to ballet and other movement-based arts, such as circus and clowning, thereby anticipating some of the practices that he was later to encounter at the Bauhaus. Kandinsky thinks that everyday, functional movement in life or on stage is so familiar as to preclude further research. However, the movement of earlier civilizations not least Greek, as revealed in artifacts, could yield new forms of expression. This recalls his work with Sacharoff and his observations on Duncan, although he does not mention either dancer directly. 
Kandinsky goes on to propose a research method for analyzing movement and spectators' response to it - a method that utilizes what was then the relatively new technology of photography: "Movement and gesture must be created and examined from the standpoint of the inner impression gained from them - of psychic experience. Both the movement of the whole body and, for example, the hand, the fingers, or just one finger, must be recorded photographically, together with accurate observations about their effects." ${ }^{, 56}$ Again, Kandinsky goes into great detail in the "Program for the Institute of Artistic Culture" and movement is a central feature of his research into a new scientific approach to art. He retains a sense of the spiritual, the emotional, and the unknown throughout. This "Program," in spite of its lack of implementation at the Institute of Artistic Culture, enunciated a substantial part of the theory that he took with him to the Bauhaus. It is essential that consideration of his work at the Bauhaus, including his publications and production, take this into account. Otherwise, his essay on Palucca, in particular, might be misunderstood. Kandinsky's writing of 1920 suggests that he is formulating his ideas afresh in the light of new technology. His work at the Bauhaus and, most especially, his analysis of photographs of Palucca, which I discuss later, need to be understood accordingly.

\section{The Bauhaus in Weimar and Dessau}

During Kandinsky's time at the Bauhaus in Weimar and Dessau between 1922, when he was appointed by Walter Gropius to teach theory of form, and 1928, when he realized his only stage composition, his interest in dance continued.

Kandinsky made further attempts to stage The Yellow Sound. In a letter to Hans Hildebrandt in 1937, he recalls attempts in 1922 to stage it at the Berlin Volksbühne and then later at the Bauhaus at Schlemmer's invitation. ${ }^{57}$ Neither production was possible because by the early 1920s, de Hartmann, who had not completed the score in 1914, was out of touch. Nonetheless, Kandinsky continued to pursue an active interest in the realization of a stage 
composition. An extract from his 1914 Bühnenkomposition Violett published by the Bauhaus in 1927 indicates a planned publication of the complete score, which unfortunately was never realized. ${ }^{58}$ A year later he accepted an invitation to design and direct Pictures at an Exhibition at the Friedrich Theater in Dessau. This 1928 event would be his only successful performance.

Kandinsky's situation at the Bauhaus can be usefully read with reference to the work and writings of Schlemmer, twenty-two years his junior. Schlemmer, whose performance work was extensive, was then director of the Bauhaus Stage. ${ }^{59}$ He had led the Weimar stage workshop since 1921, and it is his work that has become synonymous with dance at the Bauhaus. Many of his major experiments were realized at Weimar, not least Das Triadisches Ballett (The Triadic Ballet, 1922). Schlemmer's ideas on dance, theater, and abstraction, along with those of the visual artist László Moholy-Nagy, were published in the Bauhaus book Die Bühne im Bauhaus (The Theater of the Bauhaus) in $1924 .^{60}$ The Bauhaus then moved to Dessau. However, Schlemmer's published writing does not acknowledge Kandinsky directly; nor do Kandinsky's writings in his Bauhaus period cite Schlemmer directly, although both referred to each other's visual imagery in their own art works. Schlemmer does, however, mention Kandinsky and his work throughout his diaries and letters of the time. ${ }^{61}$

Kandinsky wrote prolifically. ${ }^{*}$ During his time at the Bauhaus, he continued to have his ideas published in Germany and beyond, including in a number of Bauhaus publications. Further, starting in 1919, his short essays began to appear in the prestigious German art periodical Das Kunstblatt. His 1926 essay on photographs of Palucca was the third of five such writings. In addition, he mentions dance in two of his most significant theoretical

\footnotetext{
*Lindsay and Vergo's Kandinsky: Complete Writings on Art is a testament to his publication record.
} 
writings: "Über die abstrakte Bühnensynthese" (Abstract Synthesis on the Stage), one of three contributions to a 1923 anthology published in Weimar to accompany the first Bauhaus exhibition, and his 1926 book Punkt und Linie zu Fläche (Point and Line to Plane). ${ }^{62}$ Kandinsky, aged 60, continued to think about dance, while not actively initiating new stage experiments.

Recently, there has been considerable interest in dance scholarship on Kandinsky's time at the Bauhaus, initiated by Susan Funkenstein's modernist rereading of his work with the photographs of Palucca. Nicolas Salazar Sutil, in an essay titled "Mathematics in Motion," makes a direct comparison between Kandinsky and Schlemmer. ${ }^{63}$ He argues that "by making moment [sic] abstract, Kandinsky objectified the role of the dancer to a mechanical and geometric apparatus, and so a very fundamental disconnection occurs that distances the viewer and alienates viewer from motion. Movement is relegated to an animation technique. ${ }^{\prime 64}$ His conclusion seems to be at odds with Kandinsky’s writings, wherein the artist continues to search for the spiritual in art, including dance, in the sense of discovering the ineffable in an artwork and drawing the viewer in. It is useful to keep this idea in mind when re-examining the substance of Kandinsky's writing in his Bauhaus period and when examining his contribution to ideas about the future of dance.

When Kandinsky returned to Germany in 1921, the dance situation was very different in many respects from what it had been when he left Munich in 1914. Rudolf Laban's book Die Welt des Tänzers (The World of the Dancer) had been published in Stuttgart in $1920,{ }^{65}$ and Laban's dance groups performed extensively during the early 1920s, as did Wigman's group and many other dancers. Weimar, as a city, offered few venues for the new dance, although it did have one major theater - the German National Theater, where, in 1919, the Constitution of the German Reich, or the Weimar Constitution, had been drawn up. This document is, of course, synonymous with the Germany of 1919-1933, the Weimar Republic. 
Weimar itself encapsulated many of the contradictions of the period, notably the way political control in the city shifted during the twenties. ${ }^{*}$ When, having taken a turn toward the right wing, the local Thüringen authorities withdrew funding from the school, the Bauhaus, in 1925, was forced to relocate to Dessau.

The Bauhaus provided the flourishing artistic context for experimental dance in Weimar. The 1924 book by Schlemmer, Moholy-Nagy, and Farkas Molnár, Die Bühne im Bauhaus: Bauhausbücher 4, later translated as The Theater of the Bauhaus, encapsulated and made visible this thriving milieu. ${ }^{66}$ Here, the authors laid out the Bauhaus vision in text, graphics, and photographs, incorporating dance, circus, and variety acts as parts of a new theater. ${ }^{\dagger}$ Kandinsky is neither mentioned nor included; his own vision of new abstract stage work had been published the year before in another Bauhaus anthology, Staatliches Bauhaus in Weimar 1919-23 (Bauhaus in Weimar). The historiography of dance and the Bauhaus has followed The Theater of the Bauhaus, focusing on Schlemmer and his performances and also referring to the artist Kurt Schmidt. In an essay, Funkenstein presents a detailed case showing the importance of Palucca's association with the Bauhaus, particularly during its later Dessau period, and how some of the artists recognized her affiliation formally, while other artists and students did so informally. ${ }^{67}$ Palucca is most often associated with Kandinsky by virtue of his 1926 essay. However, Funkenstein suggests that Palucca's involvement with the school was far more extensive.

\footnotetext{
* In Watching Weimar Dance (Oxford: Oxford University Press, 2014), Kate Elswit does an admirable job of exploring the complexities of the period from a dance point of view.

${ }^{\dagger}$ The 1961 English edition also includes an introduction by Gropius and an additional 1927 lecture at Dessau by Schlemmer. Walter Gropius The Theater of the Bauhaus, trans. Arthur S. Wensinger (Middletown, CT: Wesleyan, 1961).
} 
Kandinsky’s 1926 essay on four photographs of Palucca dancing, “Tanzkurven: Zu den Tänzen der Palucca" (Dance Curves: The Dances of Palucca) has been written about in some detail recently, most particularly by Funkenstein and Sutil. ${ }^{68}$ Funkenstein details how the essay came about and, in doing so, raises some important points about the commercial use of art and artists in the period. Her feminist analysis helps to recover Palucca's place in the modern dance canon and at the same time interrogates Kandinsky's approach to abstraction, suggesting that his way of depicting the female dancer's body was more open than might be expected. ${ }^{69}$ Palucca performed at the Nationaltheater in Weimar on March 18, 1925, shortly before the Bauhaus closed in that city. Charlotte Rudolph photographed the dancer later that same year. Now situated at the new Dessau home of the Bauhaus, Kandinsky, Klee, and Moholy-Nagy, were invited to write about the photographs. ${ }^{70}$ Kandinsky visited the dancer and her husband Fritz Beinert in Dresden and Kandinsky's essay was published in the March 1926 issue of Das Künstblatt, ${ }^{71}$ and then in the 1926 Palucca School brochure Palucca Tanz (Palucca Dances). Palucca's visibility increased markedly thanks to the publication of the photographs in this well-established art periodical. The secondary literature suggests that the essay arose largely as a result of the marketing strategy of Palucca's husband. ${ }^{72}$ Nonetheless, the writing stands as a testament to the relationship between Kandinsky's ideas of abstraction and dance. Kandinsky's 1920 "Program for the Institute of Artistic Culture," referred to in relation to his time in Moscow, helps understand why he took up the invitation and how it might thus be read. It was here that within a program for research into art, including dance, he had extolled the relatively new technology of photography.

"Dance Curves" consists of 266 words and four drawings that accompany four photographs of Palucca created by Rudolph over four pages of the magazine (see Figure 2). Kandinsky praises Palucca as an artist who can conceptualize form. His drawings illustrate how this works; they translate, as he puts it, "the four instantaneous photographs into 
diagrammatic form." In presenting these schematic representations, he gives us visual images of a type recognizable in his other work of the period, most especially Punkt und Linie zu Fläche (Point and Line to Plane) of later that same year. His final drawing is particularly effective; ${ }^{*}$ of the four, it best captures Palucca in action. ${ }^{73}$ Moreover, Kandinsky extends his earlier observations about the possibilities of photography for researching and analyzing dance. The "instantaneous" photographs can show part of the temporal development of a dance, he says, but what is really needed is "slow-motion photography, which extends our field of vision in a quite surprising way." ${ }^{, 74}$ One could say that Kandinsky makes a number of contributions to the future of dance here. First, he helps to publicize Palucca's art; second, he extols the way she deals with the creation of form, as illustrated by the drawings of the photographs; third, he proposes a new way forward for research into dance. Thus a clear relationship exists between his earlier ideas of dance and his ideas at this juncture.

Kandinsky himself emphasized the connection between his Bauhaus writings and his earlier Munich writings. Thus, "Über die abstrakte Bühnensynthese” of 1923 develops ideas presented in "Über Bühnenkomposition” of 1912, and Punkt und Linie zu Fläche (Point and Line to Plane), published in 1926, refers back to his 1912 book Über das Geistige in der Kunst. In both cases he mentions dance in the context of his greater theories of art, and, indeed, the later book mentions Sacharoff and Palucca, dancers from both periods. ${ }^{75}$ In Point and Line to Plane, Kandinsky takes his theories of abstract art to a far more developed statement: He refers to dance as part of his larger idea of abstraction in the arts, arguing, Fundamentally, this same abstract, law-abiding quality is most certainly the property of other art expressions. The spatial elements in sculpture and architecture, the tonal elements in music, the elements of movement in the dance, and the word elements in

\footnotetext{
${ }^{*}$ This is the fourth drawing in the original article, but appears as the second reproduction in the Lindsay and Vergo translation.
} 
poetry, all have need of a similar uncovering and a similar elementary comparison with respect to their external and their inner characteristics, which I call "sounds.,"76 Kandinsky writes explicitly of the modern dance and how it is capable of dealing with the formal play of line that he is seeking and has not found in ballet:

In the dance, the whole body - and in the new dance, every finger-draws lines with very clear expression. The "modern" dancer moves about the stage on exact lines, which he introduces in the composition of his dance as a significant element (Sacharoff). The entire body of the dancer, right down to his finger tips, is at every moment an uninterrupted composition of lines (Palucca). The use of lines is, indeed, a new achievement but, of course, is no invention of the "modern" dance: apart from the classic ballet, every people at every stage of their "evolution" work with line in the dance. ${ }^{77}$

In the following year, Kandinsky made a major statement about the new "synthetic art" that would herald the start of the twentieth-century in a "dawning spiritual epoch." Amsterdam, Arthur Müller Lehning had founded i10, a new, modernist magazine to promote abstraction in the arts. Kandinsky contributed to the first issue (dated October 1926, published 1927): an essay titled “And, Some Remarks on Synthetic Art." ${ }^{, 79}$ Here, he returned to the question of how nineteenth-century art had erected barriers between the material life and the spiritual, and how the new synthetic art could dissolve those barriers. Notably, he addressed painting, architecture, and dance. In many ways, this was his last major theorized statement on dance.

In "And, Some Remarks on Synthetic Art," he observes that the new dance can be either an end in itself or "one element within the total work-dance, music, painting (costume and staging). ${ }^{, 80}$ Moreover, he gives examples of how recent dance has been involved in the project of "undermining the walls," in Germany, through the use of acrobatic elements and, 
in Russia, through theatrical devices. Here, he returns to his idea of the walls or barriers between disciplines, echoing his writing of 1912, and reports on how dance was actually achieving what he hoped for. He refers to examples from both Russia and German art schools, citing the Bauhaus as one place where artists were breaking down barriers/walls. Presumably, this refers, at least in part, to the work of the Bauhaus Stage. The interests Kandinsky's expresses in this 1927 essay suggest something far removed from Sutil's contention that he was not interested in embodiment in dance, just animation. Kandinsky concludes his essay by reasserting the need for art to strive to leave the materialism of the past, in order to equip itself to deal with the spiritual and to achieve the "synthetic work of art." ${ }^{81}$ The synthetic work of art transcended disciplinary barriers erected in the past. Because stage composition allowed the disciplines of music, dance, and the visual arts to synthesize at the level of sound, movement, line, and color, Kandinsky thought it was the best avenue for the synthetic work. Keeping this in mind, we now look at Kandinsky's only realization of a stage composition.

Kandinsky's final contribution to a dance of the future was his staging of Modest Mussorgsky's Pictures at an Exhibition as an abstract stage work at the Friedrich-Theater in Dessau in 1928. While Kandinsky wrote only a brief reflection on it, ${ }^{82}$ the music exists in a number of recordings, the designs and Felix Klee's score with annotations have been preserved, and some evidence of the dancers' contributions exists. ${ }^{*}$ A substantial review essay written by Ludwig Grote appeared in $i 10$, the very magazine to which Kandinsky had contributed "And, Some remarks on Synthetic Art" the previous year. Grote's essay featured

\footnotetext{
* Original designs are housed in the Kandinsky Archive of the Centre Pompidou, Paris, and available online at "La Bibliothèque Kandinsky," Centre Pompidou, www.centrepompidou.fr/Collections/Kandinsky-Library. My observations are based on the latter.
} 
a photograph of the two dancers in Scene XII, The Market Place at Limoges. ${ }^{83}$ In 1983, Clark Poling gave an account of the performance itself and, more recently, Behr and Sutil revisit the work to pursue their separate arguments about Kandinsky's contribution to monumental theater and mathematical abstraction respectively. ${ }^{84}$ Moreover, the pianist Mikhail Rudy recently reconstructed Kandinsky's designs in an animated staging to accompany his solo piano recital of the work. ${ }^{85}$

Kandinsky was invited to stage Pictures at an Exhibition by Georg von Hartmann, the director of the Friedrich-Theater. Dessau's main theater had a capacity of more than 700 seats, so it was a significant undertaking. The premiere on April 4, 1928, conducted by Artur Rother, was followed by additional performances. Mussorgsky had written the music in memory of his friend Viktor Hartmann, and each of the named sections refers to one of Hartmann's figurative paintings and designs. Kandinsky made designs for sixteen scenes: the ten pictures depicted by Mussorgsky and the interspersed Promenade sections. However, Kandinsky's designs for the performance of the music were mainly non-figurative, many of them clearly abstract, consistent in this way with Kandinsky's paintings of the period. Lines and geometric shapes predominated. However, some designs, such as that for Scene XII, The Market Place at Limoges, and Scene XVI, The Great Gate of Kiev, contained elements that suggested person or place. Kandinsky realized eight of the scenes and the Promenade sections with moving backdrops, staging, props, and lights. Two of the scenes-X, Samuel Goldenberg and Schmuyle, and XII, The Market Place at Limoges - incorporated two dancers. The costume designs for the dancers can be read in a number of ways. Kandinsky makes no attempt to disguise the figure and, indeed, in the design for the Woman in The Market Place, she clearly carries a basket of market goods. At the same time, one sees a hint of the sort of designs emphasizing line and shape rather than the dancer's figure that 
Schlemmer used at the Bauhaus (see Figure 3). Poling suggests that the dancers served diverse purposes:

The two dancers in the production served quite different functions in the scenes in which they participated. In Scene XII, The Marketplace in Limoges . . . they were costumed naturalistically and stood on or near the small pedestals at the sides of the backdrop bearing a map image, presumably gesticulating to indicate the haggling described in the program. In Scene X, Samuel Goldenberg and Schmuyle . . on the other hand, each stood behind a vertical rectangle of transparent material on which their silhouettes were projected by backlighting. Circles in these props at times were lit from the front while they rotated at different speeds, evoking the conversation of the two protagonists. ${ }^{86}$

In the photograph accompanying Grote's review essay, the dancers stand on the low pedestals. While their costumes are somewhat naturalistic, their gestures do not seem to be. Grote says of the performance that the stage space seemed unreal, like the space in Kandinsky's paintings, and that the whole effect was magical. ${ }^{87}$ The overall picture was in constant motion, creating a dramatic effect through the changing composition. Poling concludes, "Kandinsky united pictorial, theatrical and musical elements in this production and thus achieved his goal of creating a synthetic work, which extended his painting into a magical realm of spatial and temporal dimensions."

Kandinsky reflected on the performance in a short essay published in Das Künstblatt, which he accompanied with a reproduction of his design for the final scene, The Great Gate of Kiev (see Figure 4). He returns to an idea expressed in his 1920 "Program for the Institute of Artistic Culture" when he says that the music does not "depict" anything, but rather Mussorgsky communicated his experiences at the exhibition of Hartmann's work, and hence they "assumed musical form." In fact, this was why Kandinsky accepted the invitation to 
stage it. ${ }^{89}$ His explanation recalls his earlier synesthetic experiments with Sacharoff and de Hartmann in Munich, where the musician improvised music in response to Kandinsky's watercolors and then the dancer danced the music. Bearing this in mind, his inclusion of two dancers in what is otherwise a staging of form and color makes sense. Kandinsky says, "With the exception of two scenes_-'Samuel Goldenberg and Schmuyle' and 'Market Place at Limoges' (for which I used in addition two dancers) — the entire staging was 'abstract.",90 Kandinsky had been including dance within his idea of art for two decades. It was a thread to which he kept returning, prompted by various events. When he describes the staging as "abstract," placing the term in quotes he suggests that, while a difference exists between these two scenes and all the rest, it is one of emphasis rather than a substantive, formal one. The difference was, of course, in his use of dancers, but he chose to do so, and to costume them in a way that did not disguise their human nature. So it could be said that in this realization of an abstract work of theater as form and light, Kandinsky recognized the costumed, dancing human figure as an equal contributor, although clearly the dancers contributed something different from the inanimate shapes and colors of the staging.

A number of scholars, including Poling and Behr, conclude that Pictures at an Exhibition was the climax to Kandinsky's work toward a monumental or synthetic theater. ${ }^{91}$ It was certainly the only time that he realized a theatrical performance. On the performance, Lindsay and Vergo cite Nina Kandinsky's memoir: "Her husband's greatest ambition was to create a large-scale, multimedia ballet. This wish was never realized. Kandinsky's most important step in this direction was the staging of Mussorgsky's Pictures at an Exhibition." 92 However, if we think of this work in terms of the dance of the future, and Kandinsky's express and consistent vision, there is much to suggest that, in 1928, it achieved precisely that. 


\section{Conclusion}

Wassily Kandinsky has achieved lasting recognition as a painter and theorist. He completed a considerable portion of his most significant paintings and writings between 1908 and 1928, while he was developing his ideas about abstraction. In this period he articulated a vision for a dance of the future that, though glimpsed only briefly in practice, remains in the evidence available to historians. He developed this vision consistently within his art and writing over two decades. His unique contribution was to be one of the first artists, if not the first, to articulate a twentieth-century modernist theory of dance as part of a new synthesis of the arts. He dealt with matters of abstraction, expression, and spirituality in a consistent and coherent way before most modern dancers did. Kandinsky only achieved one performance reflecting his ideas, but the vision in that performance anticipated many later ideas about dance. He explored dance in relationship to form, light, color, and line in ways that anticipated experiments of the twenty-first century, especially intermedial performances using new technologies. In both the performance of Pictures at an Exhibition and in the writings that led up to it, he envisioned a dance of the future. This vision was unique in its period and still has much to offer.

\section{Notes}

\footnotetext{
${ }^{1}$ Wassily Kandinsky, The Art of Spiritual Harmony, trans. M. T. H. Sadler (Boston and New York: Houghton Mifflin, 1914), 100; Wassily Kandinsky, On the Spiritual in Art, trans. and ed. Hila Rebay (New York: Solomon R Guggenheim Foundation, 1946), 87; Wassily Kandinsky, On the Spiritual in Art, trans. Kenneth C. Lindsay and Peter Vergo, in Kandinsky: Complete Writings on Art, eds. Kenneth C. Lindsay and Peter Vergo (1982; repr., New York: Da Capo, 1994), 206.

${ }^{2}$ See, in particular, Thomas J. Hines, Collaborative Forms (Kent, OH: Kent State University Press, 1991); Susan L. Funkenstein, “Engendering Abstraction: Wassily Kandinsky, Gret
} 
Palucca, and 'Dance Curves,"” MODERNISM/modernity, vol. 14, no. 3 (2007): 389-406;

Nicolas S. Sutil, "Mathematics in Motion: A Comparative Analysis of the Stage Works of Schlemmer and Kandinsky at the Bauhaus," Dance Research, vol. 32, no. 1 (2014): 23-42.

${ }^{3}$ Adrian Glew, introduction to Wassily Kandinsky, Concerning the Spiritual in Art (Boston: MFA Publications, 2006), vii.

${ }^{4}$ Kandinsky, The Art of Spiritual Harmony, 49-51.

${ }^{5}$ Kandinsky, On the Spiritual in Art, trans. Lindsay and Vergo, 205.

${ }^{6}$ Kandinsky, The Art of Spiritual Harmony, 100-101.

${ }^{7}$ Kandinsky, On the Spiritual in Art, trans. Lindsay and Vergo, 206.

${ }^{8}$ Isadora Duncan, Der Tanz Der Zukunft (The Dance of the Future): Eine Vorlesung (A Lecture), ed. Karl Federn (Leipzig: Eugen Diederichs, 1903), 11.

${ }^{9}$ Isadora Duncan, “The Dance,” Theatre Arts Magazine, vol. 2, no. 1 (December 1917): 2122; Isadora Duncan, The Art of the Dance, ed. Sheldon Cheney (New York: Theatre Arts Books, 1928).

${ }^{10}$ Duncan, Der Tanz Der Zukunft, 19.

${ }^{11}$ Ibid., 26.

${ }^{12}$ Naoko Kobayashi-Bredenstein, Wassily Kandinskys Frühe Bühnenkompositionen: Über Korperlichkeit Und Bewegung (Berlin: Walter de Gruyter, 2012), 61-62.

${ }^{13}$ Ernst Schur, Der Moderne Tanz (Munich: Gustav Lammers, 1910).

${ }^{14}$ See Edward Ross Dickinson, “'Must We Dance Naked?’: Art, Beauty, and Law in Munich and Paris, 1911-1913," Journal of the History of Sexuality, vol. 20, no. 1 (January 2011): 95131.

${ }^{15}$ Claudia Jeschke and Gabi Vettermann, "Isadora Duncan, Berlin and Munich in 1906: Just an Ordinary Year in a Dancer's Career," Dance Chronicle, vol. 18, no. 2 (1995): 217-29. 
${ }^{16}$ John Ernest Crawford Flitch, Modern Dancing and Dancers (London: Grant Richards, 1912); Hans Brandenburg, Der Moderne Tanz (Munich: Georg Müller, 1913).

${ }^{17}$ M. T. H. Sadler, in Kandinsky, The Art of Spiritual Harmony, 100, fn.

${ }^{18}$ Ian Strasfogel, "The Creation of The Yellow Sound," The Yellow Sound: Marymount Manhattan Theater [program], 1982; Rainer Stamm, “Alexander Sacharoff: Dance and the Fine Arts," in Die Sacharoffs: Zwei Tänzer aus dem Umkreis des Blauen Reiters (Two Dancers within the Blaue Reiter Circle), eds. Frank-Manuel Peter and Rainer Stamm (Köln: Wienand Verlag, 2002), 11-45; Shulamith Behr, "Kandinsky and Theater: 'The Monumental Artwork of the Future,", in Vasily Kandinsky and the Total Work of Art: From Blaue Reiter to Bauhaus (New York: Neue Galerie, 2013), 65-85.

${ }^{19}$ Wassily Kandinsky, "Report to the Pan-Russian Conference, 1920," in Lindsay and Vergo, Kandinsky: Complete Writings on Art, 474, (first published in Vestnik Rabotnikov Iskusstv, Bulletin of Art Workers).

${ }^{20}$ Vivian E. Barnett, Kandinsky Watercolours: Catalogue Raisonée, Volume One, 1900-1921 (London: Sotheby’s Publications, 1992), 215.

${ }^{21}$ Stamm, “Alexander Sacharoff,” 21-22.

${ }^{22}$ Ibid., 22-23.

${ }^{23}$ Peg Weiss, Kandinsky in Munich: The Formative Jugendstil Years (Princeton, NJ: Princeton University Press, 1979), 139-41.

${ }^{24}$ Ibid., 140.

${ }^{25}$ Kandinsky, The Art of Spiritual Harmony; Wassily Kandinsky, Concerning the Spiritual in Art, trans. M.T.H. Sadler (1914; repr., New York: Dover, 1977); Wassily Kandinsky, On the Spiritual in Art, trans. Hila Rebay (New York: Solomon R Guggenheim Foundation, 1946); Wassily Kandinsky, Concerning the Spiritual in Art and Painting in Particular, trans. M. T. H. Sadleir and re-trans. by Francis Golffing, Michael Harrison, and Ferdinand Osterstag 
(New York: Wittenborn, Schultz, 1947); Wassily Kandinsky, Concerning the Spiritual in Art, MFA Publications).

${ }^{26}$ Lindsay and Vergo, Kandinsky: Complete Writings on Art, 116-17.

${ }^{27}$ Kandinsky, The Art of Spiritual Harmony, 111-12.

${ }^{28}$ Ibid., 112.

${ }^{29}$ Wassily Kandinsky, "Content and Form ["Soderzhanie i forma”] Salon 2 . . . (Odessa), 1910-1911," in Lindsay and Vergo, Kandinsky: Complete Writings on Art, 87.

${ }^{30}$ Ibid., 88 .

${ }^{31}$ Ibid., 89.

${ }^{32}$ Behr, "Kandinsky and Theater"; Hines, Collaborative Forms; Kobayashi-Bredenstein, Wassily Kandinskys Frühe Bühnenkompositionen; Stamm, “Alexander Sacharoff”; Susan A. Stein, “Kandinsky and Abstract Stage Composition: Practise and Theory, 1909-12," Art Journal, vol. 43, no. 1 (1983): 61-66.

${ }^{33}$ Weiss, Kandinsky in Munich, 92-103.

${ }^{34}$ Georg Fuchs, Die Schaubühne der Zukunft (Berlin: Schuster \& Loeffler, 1905); Georg Fuchs, Der Tanz (Stuttgart: Strecker and Schröder, 1906); Georg Fuchs, Die Revolution des Theaters, Ergebnisse aus dem Münchener Künstlertheater (Munich: Georg Müller, 1909); Georg Fuchs, Revolution in the Theatre: Conclusions Concerning the Munich Artists' Theatre, trans. Constance C. Kuhn (Ithaca, NY: Cornell University Press, 1959).

${ }^{35}$ Lindsay and Vergo, Kandinsky: Complete Writings on Art, 260, 263.

${ }^{36}$ Ibid., 264.

${ }^{37}$ Wassily Kandinsky, Yellow Sound, in Lindsay and Vergo, Kandinsky: Complete Writings on Art, 281.

${ }^{38}$ Strasfogel, "The Creation of The Yellow Sound," n.p. 
${ }^{39}$ Kandinsky, Yellow Sound, in Lindsay and Vergo Kandinsky: Complete Writings on Art, 281.

${ }^{40}$ Diary entry, December 1912, in The Letters and Diaries of Oskar Schlemmer, ed. Tut Schlemmer, trans. Krishna Winston (Middletown, CT: Wesleyan University Press, 1972), $7-$ 8

${ }^{41}$ Mary Wigman, Die sieben Tänze des Lebens-Tanzdichtung (Jena, Germany: Diedrichs, 1921).

${ }^{42}$ Arnold Schoenberg, letter to Kandinsky August 19, 1912, in Jelena Hahl-Koch, Arnold Schoenberg Wassily Kandinsky: Letters, Pictures and Documents, trans. John C. Crawford (London: Faber \& Faber, 1984), 54.

${ }^{43}$ Hugo Ball, "Kandinsky [Lecture] Zurich April 7, 1917," in Flight Out of Time: A Dada Diary, ed. John Elderfield, trans. Ann Raimes, (1974; repr., Berkeley: University of California Press, 1996), 233.

${ }^{44}$ Schur, Der Moderne Tanz; Brandenburg, Der Moderne Tanz.

${ }^{45}$ Letter dated May 17, 1914, cited in Klaus Lankheit, "A History of the Almanac," in The Blaue Reiter Almanac, ed. Klaus Lankheit (London: Thames and Hudson, 1974), 33.

${ }^{46}$ Hugo Ball, Flight Out of Time, 10.

${ }^{47}$ Funkenstein, "Engendering Abstraction”; Behr, "Kandinsky and Theater"; Sutil, "Mathematics in Motion."

${ }^{48}$ Wassily Kandinsky, "Program for the Institute of Artistic Culture," in Lindsay and Vergo, Kandinsky: Complete Writings on Art, 455-72.

${ }^{49}$ Lindsay and Vergo, Kandinsky: Complete Writings on Art, 455-57; Clark V. Poling, "Kandinsky: Russian and Bauhaus Years, 1915-1933," in Kandinsky: Russian and Bauhaus Years, 1915-1933 (New York: Solomon R. Guggenheim Foundation, 1983), 27-30. 
${ }^{50}$ See, for instance, Irma Duncan and Alan Ross MacDougall, Isadora Duncan's Russian

Days and Her Last Years in France (London: Victor Gollancz, 1929).

${ }^{51}$ Kandinsky, "Program for the Institute of Artistic Culture," 457.

52 Ibid., 464.

${ }^{53}$ Ibid., 459.

${ }^{54}$ Ibid.

${ }^{55}$ Ibid., 466.

${ }^{56}$ Ibid., 467.

${ }^{57}$ Wassily Kandinsky, letter to Hans Hildebrandt (1937) cited in Strasfogel, "The Creation of The Yellow Sound," n.p.

${ }^{58}$ Wassily Kandinsky, “aus 'violett,' romantisches bühnenstück von Kandinsky,” bauhaus, vol. 1 , no. 3 (July 1927): 6 .

${ }^{59}$ Walter Gropius, ed. The Theater of the Bauhaus, trans. Arthur Wensinger (Middletown, CT: Wesleyan, 1961).

${ }^{60}$ Oskar Schlemmer, László Moholy-Nagy, and Farkas Molnár, Die Bühne im Bauhaus.

Bauhausbücher 4, eds. Walter Gropius and László Moholy-Nagy (Munich: Albert Langen, 1924).

${ }^{61}$ Schlemmer, The Letters and Diaries of Oskar Schlemmer.

${ }^{62}$ Wassily Kandinsky, “Über die abstrakte Bühnensynthese,” in Staatliches Bauhaus in Weimar 1919-1923, ed. Karl Nierendorf (Weimar: Bauhaus-Verlag, 1923), 142-44; Wassily Kandinsky, Punkt und Linie zu Fläche (Point and Line to Plane) (Munich: Albert Langen Verlag, 1926).

${ }^{63}$ Funkenstein, "Engendering Abstraction"; Susan Funkenstein, "Picturing Palucca at the Bauhaus," in New German Dance Studies, eds. Susan Manning and Lucia Ruprecht (Urbana: University of Illinois Press, 2012), 45-62; Sutil, "Mathematics in Motion." 
${ }^{64}$ Sutil, "Mathematics in Motion," 20

${ }^{65}$ Rudolf von Laban, Die Welt des Tänzers: Fünf Gedankenreigen (Stuttgart: Walter Seifert, 1920).

${ }^{66}$ Schlemmer, Moholy-Nagy, and Molnár, Die Bühne im Bauhaus.

${ }^{67}$ Funkenstein, "Picturing Palucca at the Bauhaus."

${ }^{68}$ Funkenstein, "Engendering Abstraction"; Funkenstein, "Picturing Palucca at the Bauhaus";

Sutil, "Mathematics in Motion."

${ }^{69}$ Funkenstein, "Engendering Abstraction."

${ }^{70}$ Ibid.

${ }^{71}$ Wassily Kandinsky, "Tanzkurven: Zu den Tänzen der Palucca” (Dance Curves: The Dances of Palucca), Das Kunstblatt, vol. 10, no. 3 (1926): 117-21.

${ }^{72}$ Funkenstein, "Engendering Abstraction"; Funkenstein, "Picturing Palucca at the Bauhaus"; Sutil, "Mathematics in Motion."

${ }^{73}$ Kandinsky, "Tanzkurven: Zu den Tänzen der Palucca,” 120, reproduced in translation as "Dance Curves: The Dances of Palucca," in Lindsay and Vergo, Kandinsky: Complete Writings on Art, 521. Kandinsky, “Tanzkurven: Zu den Tänzen der Palucca,” Kandinsky, Punkt Und Linie Zu Fläche.

74 “Dance Curves: The Dances of Palucca," Lindsay and Vergo, Kandinsky: Complete Writings on Art, 522.

${ }^{75}$ Wassily Kandinsky, Point and Line to Plane, trans. Hila Rebay and Howard Dearstyne (New York: Solomon R. Guggenheim Foundation, 1947).

${ }^{76}$ Ibid., 83

${ }^{77}$ Ibid., 100

${ }^{78}$ Wassily Kandinsky, “And, Some Remarks on Synthetic Art (Und, Einiges über Synthetische Kunst)," in Lindsay and Vergo, Kandinsky: Complete Writings on Art, 716, 
originally published as "Einiges über Synthetische Kunst," Internationale Revue i10, vol. 1, no. 1 (January 1927): 4-10.

${ }^{79}$ Kandinsky, “And, Some Remarks on Synthetic Art.”

${ }^{80}$ Ibid., 713.

${ }^{81}$ Ibid., 717.

${ }^{82}$ Wassily Kandinsky, "Modeste Mussorgsky: Bilder einer Ausstellung” (Pictures at an Exhibition), Das Kunstblatt, vol. 14, no. 8 (1930): 249-51.

${ }^{83}$ Ludwig Grote, "Bühnenkomposition von Kandinsky," Internationale Revue i10, vol. 2, no. 13 (August 1928): 4-5.

${ }^{84}$ Poling, "Kandinsky: Russian and Bauhaus Years"; Funkenstein, "Engendering Abstraction"; Sutil, "Mathematics in Motion."

${ }^{85}$ Steve Smith, "Museum Gathers Piano, Paintings and Video in a Blended Work," New York Times, September 29, 2012, C5.

${ }^{86}$ Poling, "Kandinsky: Russian and Bauhaus Years," 72.

${ }^{87}$ Grote, "Bühnenkomposition von Kandinsky," 5.

${ }^{88}$ Poling, "Kandinsky: Russian and Bauhaus Years," 73.

89 "Pictures at an Exhibition," Lindsay and Vergo, Kandinsky: Complete Writings on Art, 750, originally published as Wassily Kandinsky, “Modeste Mussorgsky: Bilder einer Ausstellung."

${ }^{90}$ Ibid.

${ }^{91}$ Poling, "Kandinsky: Russian and Bauhaus Years"; Behr, "Kandinsky and Theater."

${ }^{92}$ Wassily Kandinsky, "Pictures at an Exhibition," in Lindsay and Vergo, Kandinsky:

Complete Writings on Art, 749, referring to Nina Kandinsky, Kandinsky und ich (Munich: Kindler, 1976), 159. 
MICHAEL HUXLEY is currently reader in dance at De Montfort University, Leicester, United Kingdom, and director of its Centre for Interdisciplinary Research in Dance. His articles have been published in a number of books, and he has written for a range of dance periodicals, including Research in Dance Education; Journal of Dance and Somatic Practices; Journal of Dance, Movement and Spiritualities; and Discourses in Dance. His published research has focused on early modern dance and dance history. Huxley served as a board member of the Congress on Research in Dance for ten years; as chair of the editorial board for Dance Research Journal (2005-2010); as senior academic adviser in dance and chair of the advisory board for the UK Subject Centre PALATINE; and as project leader for De Montfort University's Centre for Excellence in Performance Arts (2005-2010). His most recent book is The Dancer's World 1920-1945: Modern Dancers and Their Practices Reconsidered (Basingstoke, UK: Palgrave, 2015).

\section{Figure 1}

Wassily Kandinsky, Composition VI, 1913. The State Hermit- age Museum, St. Petersburg. Photograph (C) The State Hermitage Museum. Photo by Vladimir Terebenin. 